\title{
THE FUNCTIONAL OUTCOME OF COMMINUTED CLOSED MIDSHAFT FRACTURE CLAVICLE TREATED WITH LOCKING COMPRESSION PLATE: A PROSPECTIVE STUDY
}

\author{
Mahendra Panwar', R. K. S. Dhakad², Sameer Gupta ${ }^{3}$ \\ ${ }^{1}$ Senior Resident, Department of Orthopaedics, Jay Arogya Hospital and G. R. Medical College, Gwalior, Madhya Pradesh. \\ ${ }^{2}$ Associate Professor, Department of Orthopaedics, Jay Arogya Hospital and G. R. Medical College, Gwalior, Madhya Pradesh. \\ ${ }^{3}$ Professor and HOD, Department of Orthopaedics, Jay Arogya Hospital and G. R. Medical College, Gwalior, Madhya Pradesh.
}

\section{ABSTRACT}

Fracture of the clavicle accounts for approximately 5\% to $10 \%$ of all fractures and up to $44 \%$ of injuries to the shoulder girdle. Fractures of the clavicle have been traditionally treated nonoperatively. The proponents of early fixation of fresh clavicular fractures to prevent complications like malunion and nonunion emphasize the value of accurate reduction and rigid fixation in affording quick pain relief and promoting early functional recovery.

\section{METHOD}

The present study was carried out from August 2012 to Sept. 2014 at Orthopaedic Department in JA. Hospital attached to GR. Medical College, Gwalior. During this period 38 patients of comminuted mid shaft fracture clavicle treated with plating. All patients are regularly followed up, examined, serial x-rays are taken and functional outcome is assessed.

\section{RESULTS}

The duration of union in patients with comminuted midshaft clavicle fractures range from 8-12 weeks (Average 10.4 weeks) in 35 patients. Three patients went for delayed union. Fracture treated with plate and screws, 29 patients (76\%) had excellent functional outcome, good functional outcome in 6 patients (16\%) and fair functional outcome in 3 patients (8\%).

\section{CONCLUSION}

In this study early primary plate fixation of comminuted midshaft clavicular fractures result in improved patient-oriented outcomes, improved surgeon-oriented outcomes, earlier return to function and decreased rates of nonunion and malunion.

\section{KEYWORDS}

Clavicle, Midshaft, Comminuted Fracture, Plate.

HOW TO CITE THIS ARTICLE: Mahendra Panwar, R. K. S. Dhakad, Sameer Gupta. "The Functional Outcome of Comminuted Closed Midshaft Fracture Clavicle Treated with Locking Compression Plate: A Prospective Study." Journal of Evolution of Medical and Dental Sciences 2015; Vol. 4, Issue 99, December 10; Page: 16439-16443, DOI: 10.14260/jemds/2015/2438

\section{INTRODUCTION}

Fracture of the clavicle accounts for approximately $5 \%$ to $10 \%$ of all fractures and up to $44 \%$ of injuries to the shoulder girdle. About $70 \%$ to $80 \%$ of these fractures are in the middle third of the bone and less often in the lateral third $(12 \%$ to $15 \%$ ) and medial third (5\% to $8 \%)^{1}$

Fractures of the clavicle have been traditionally treated nonoperatively. Although many methods of closed reduction have been described, it is recognized that reduction is practically impossible to maintain and a certain amount of deformity and disability is expected in adults. ${ }^{1}$ In the past few years several publications have described about poor outcomes like malunion and nonunion (15\%) after conservative treatment of severely displaced clavicular fractures. ${ }^{2,3}$ The proponents of early fixation of fresh clavicular fractures to prevent complications like malunion

Financial or Other, Competing Interest: None.

Submission 20-11-2015, Peer Review 21-11-2015,

Acceptance 02-12-2015, Published 09-12-2015.

Corresponding Author:

Dr. Mahendra Panwar,

Room No. 54, Senior Boys Hostel,

G. R. Medical College,

Gwalior-474001, Madhya Pradesh.

E-mail: neer.panwar@gmail.com

DOI:10.14260/jemds/2015/2438 and nonunion emphasize the value of accurate reduction and rigid fixation in affording quick pain relief and promoting early functional recovery. ${ }^{4}$

\section{AIMS AND OBJECTIVES}

- To study the rate of the fracture union and complication in operative treatment of comminuted mid shaft clavicle fracture.

- To evaluate the functional outcome of shoulder joint after treatment of comminuted mid shaft clavicle fracture.

\section{METHODOLOGY}

The present study was carried out from August 2012 to Sept. 2014 at Orthopaedic Department in J.A. Hospital attached to G.R. Medical College, Gwalior. During this period, 38 patients of comminuted midshaft fracture clavicle treated with locking compression plate.

\section{Inclusion Criteria}

- Patients, an Age 16-60y.

- No medical contraindication for anaesthesia provided informed consent.

- Sex:- Both male and female. 


\section{Exclusion Criteria}

- Skeletally immature patient.

- Compound fracture.

- Fracture associated with any pathological process.

- A medical contraindication to surgery or anaesthesia.

General information (Name, age, sex, occupation and address) were noted. Then a detailed history was elicited regarding mode of injury like fall on the shoulder, road traffic accident, etc. Enquiry was made to note site of pain and swelling over the affected clavicle. Past medical illness and family history, general condition of the patients was examined for pallor, pulse rate and BP. Respiratory and cardiovascular system were examined for any abnormalities.

\section{MIDDLE THIRD CLAVICLE FIXATION}

Instruments used for plate fixation,

- LCP anterior superior plate (S shaped).

- $2.7 \mathrm{~mm}$ drill bit.

- $3.5 \mathrm{~mm}$ universal drill guide.

- Hand drill/pneumatic drill.

- $3.5 \mathrm{~mm}$ tap for cortical screw.

- Depth gauge.

- $3.5 \mathrm{~mm}$ cortical screw of varying sizes $(12-22 \mathrm{~mm})$.

- Hexagonal screw driver.

- General instruments like retractor, periosteal elevator, reduction clamps and bone lever.

\section{TECHNIQUE FOR PLATE AND SCREW FIXATION}

- Patient in supine position with one towel/small pillow in between the scapula.

- Entire upper limb from base of neck to hand were prepared and draped.

- About 7-9cms, incision was made in the anterior aspect centering of clavicle over the fracture site.

- The skin subcutaneous tissue and platysma were divided without undermining the edges.

- The overlying fascia and periosteum were next divided. The osseous ends was freed from surrounding tissue.

- Minimal soft tissue and periosteum dissection was done.

- Fracture fragments were reduced and plate was applied over the superior aspect of the clavicle.

- At the junction of the medial and middle third of the clavicle, the inferior surface is exposed so that a protective instrument can be inserted during drilling to prevent injury to neuorvascular structure underneath it.

- The plate was fixed to the medial and lateral fragment with $3.5 \mathrm{~mm}$ cortical screw and at least three screws in medial and lateral fragment were applied. (Fig.1)

Wound was closed in layers after ensuring meticulous hemostasis and sterile dressing was applied.5,6,7,8,9

\section{Postoperative Care}

- Patients were kept nil orally for 4 to 6 hours postoperatively.

- Intravenous fluids were given as needed.

- Antibiotics were continued for 10 days.

- Analgesics and tranquilizers were given according to the needs of the patient.

- The operated upper limb was immobilized in an arm pouch.
- Check x-rays were taken to study the alignment of fracture fragments.

- The wound was inspected at 3rd or 4 th postoperative day.

- Suture removal was done on 10 th postoperative day.

- Patients were discharged with the arm pouch.

- Rehabilitation of the affected arm was started at the end of 2 weeks. Gentle pendulum exercises to the shoulder in the arm pouch were allowed. At 4 to 6 weeks gentle active range of motion of the shoulder was allowed, but abduction is limited to 80 degrees. At 6 to 8 weeks, active range of motion in all planes were allowed.

\section{Followup}

- Regular followup for every 4 weeks was done.

- Local examination of the affected clavicle for tenderness, instability deformity and shoulder movements were assessed.

- X-rays were taken at each followup visits to know about progressive fracture union and implant position. Rehabilitation of the affected extremity was done according to the stage of fracture union and time duration from day of surgery.

- Patients were followed up till radiological union.

- The functional outcome were assessed by Constant and Murley score. ${ }^{10,11}$

\section{CONSTANT AND MURLEY SCORING}

The patients are graded as follows.

\section{CATEGORY}

\section{A) SUBJECTIVE}

1) Pain - 15 Points

No pain - 15

Bearable pain - 10

Disabling pain - 5

2) Activities of daily living:- 20 Points

Ability to perform full work - 04

Ability to perform Leisure activities/Sports - 04

Unaffected sleep - 02

Level at which work can be done

Up to Waist - 02

Up to Xyphoid - 04

Up to Neck - 06

Up to Head - 08

Above head - 10

\section{B) OBJECTIVE}

RANGE OF MOVEMENTS: 40 POINTS

a) Active flexion without pain

00 - 30 Degrees : 00

31-60 Degrees : 2

61-90 Degrees : 4

91-120 Degrees : 6

121-150 Degrees : 8

>151 Degrees : 10

b) Functional External Rotation

Hand behind head with elbow forwards - 2

Hand behind head with elbow backwards - 4

Hand above head with elbow forwards - 6

Hand above head with elbow backwards - 8

Full elevation from on top of head - 10 
c) Active abduction without pain

With dorsum of hand on back, head of third metacarpal reaches,

00 - 30 Degrees : 00

31-60 Degrees : 2

61-90 Degrees : 4

91-120 Degrees : 6

121-150 Degrees : 8

$>151$ Degrees : 10

d) Functional internal rotation

Ipsilateral buttock : 2

S1 spinous process : 4

L3 spinous process : 6

T12 spinous process : 8

$\mathrm{T} 7$ spinous process : 10

e) Strength of abduction : 25 Points

A normal shoulder in a 25-year-old man resists 25 pounds without difficulty. The score given for normal power is 25 points with proportionately less for less power. Patients were graded as below with a maximum of 100 points.

\begin{tabular}{|c|c|}
\hline Total Score & Result \\
\hline $90-100$ & Excellent \\
\hline $80-89$ & Good \\
\hline $70-79$ & Fair \\
\hline $0-70$ & Poor \\
\hline
\end{tabular}

\section{RESULTS AND OBSERVATIONS}

The present study consists of 38 patients of comminuted midshaft clavicle fracture. All were treated surgically with locking compression plate and screw between August 2012 to Sept. 2014. All the patients were available for follow-up and they were followed every 6 weeks. Results were analyzed both clinically and radiologically.

In comminuted midshaft clavicle fractures direct injury occurred in 38 patients (100\%), among them 10 patients (26\%) were due to fall on outstretched hand from two wheeler, 28 patients (74\%) were due to road traffic accident.

The majority were males, 33 patients $(86 \%)$ and females were 5 patients (14\%) and 21 patients (55\%) of left sided fracture and 17 patients (45\%) of right sided fracture.

In this present study, there were 38 patients $(100 \%)$ of comminuted mid shaft clavicle fracture where Robbinson 2B1 (Simple or single butterfly fragment) 24 patients (63\%) were Robbinson 2B2 (Comminuted or segmental) 14 patients (37\%).

All the patients in comminuted midshaft clavicle fracture were closed type. There were no associated medical illness in any patient.

In comminuted midshaft clavicle fracture, 38 patients $(100 \%)$ where $34(89 \%)$ patients were operated in the first week and 4 patients (11\%) were operated in the second week due to fixed OT days in Hospital.

All the patients were operated under general anaesthesia.

In comminuted midshaft clavicle fracture, 38 patients $(100 \%)$ treated surgically where 35 patients $(92 \%)$ united at the end of 12 weeks (Fig. 2 and 3). In 4 patients (8\%) delayed union occurred. (Table-1).
In comminuted midshaft clavicle fracture fixation, 2 patients (5\%) had hypertrophic skin scar and in 2 patients (5\%) plate prominence occurred. One patient (2\%) had superficial infection. In 1 patient (2\%) plate loosening is seen. In 3 patients (8\%) delayed union occurred, which went for malunion and in 1 patient (2\%) plate breakage occurred. (Table-2).

In this study on 38 patients (100\%) with comminuted midshaft clavicle treated with locking compression plate, 29 patients $(76 \%)$ had excellent functional outcome, good functional outcome in 6 patients $(16 \%)$ and fair functional outcome in 3 patients (8\%). (Table-3)(Fig. 4-7).

\begin{tabular}{|c|c|c|}
\hline \multirow{2}{*}{ Time of Union } & Operative \\
\cline { 2 - 3 } & 35 & \% \\
\hline 8-12 week & 3 & 92 \\
\hline 12-18 weeks & - & 8 \\
\hline$>18$ weeks & - & - \\
\hline Non Union & Table 1 \\
\hline \multicolumn{2}{|c|}{} \\
\hline
\end{tabular}

\begin{tabular}{|c|c|c|c|}
\hline & Types & No. of Cases & \% \\
\hline \multirow{4}{*}{ Minor } & Hypertrophic skin scar & 2 & 5 \\
\cline { 2 - 4 } & Plate prominence & 2 & 5 \\
\cline { 2 - 4 } & Infection (superficial) & 1 & 2 \\
\cline { 2 - 4 } & Plate loosening & 0 & 0 \\
\cline { 2 - 4 } & Delayed union & 3 & 8 \\
\hline \multicolumn{3}{|c|}{ Table 2 } \\
\hline
\end{tabular}

\begin{tabular}{|c|c|c|}
\hline \multirow{2}{*}{ Functional Outcome } & \multicolumn{2}{|c|}{ Operative } \\
\cline { 2 - 3 } & No. & $\mathbf{\%}$ \\
\hline Excellent & 29 & 76 \\
\hline Good & 6 & 16 \\
\hline Fair & 3 & 8 \\
\hline Poor & - & - \\
\hline Total & $\mathbf{3 8}$ & $\mathbf{1 0 0}$ \\
\hline \multicolumn{3}{|c|}{ Table 3 } \\
\hline
\end{tabular}

\section{DISCUSSION}

Clavicle fractures are usually treated conservatively. In a study conducted to analyze the results of conservative treatment by Hill et al. ${ }^{3}$ in 1997, Nordqvist et al. ${ }^{12}$ in 1998 and Robinson et al.13 in 2004 found poor results following conservative treatment of displaced middle third clavicle fracture. Conservative treatment of displaced lateral third clavicle fracture has higher rate of non-union and residual shoulder dysfunction as showed by Edwards et al.14 in 1992. So there are specific indication like displacement with or without comminuted middle third.

Clavicle fracture (Robinson Type-2 B1, 2B2) and displaced lateral third clavicle fracture (Robinson Type-3 B1, 3B2) for which operative treatment is needed.

The present study of patients with middle third clavicle fractures is compared with Bostman et al. ${ }^{15}$ study which treated only middle third clavicle fractures; in this totally 103 patients were treated by early open reduction and internal fixation with plate and screws. 


\section{Mechanism of Injury}

In comminuted midshaft clavicle fractures, direct injury occurred in 38 patients (100\%); among them 10 patients (26\%) were due to fall on shoulder from two wheeler, 28 patients (74\%) were due to road traffic accident.

In Bostman et al. ${ }^{15}$ study, the mechanism of injury was due to fall from the two wheeler in 38 patients $(36.8 \%)$, slipping and fall in 24 patients $(23.30 \%)$, motor vehicle accident in 19 patients (18.45\%) and sports injury in 22 patients $(21.36 \%)$. This shows direct injury to the shoulder is the common cause of this fracture.

\section{Age Incidence}

In this study, majority of the patients were with comminuted midshaft clavicle fracture, i.e., 16 patients (42\%) were in the age group of 18-28 years. The youngest patient was 18 years and oldest patient was 56 years. The average patient age was 33 years.

In Bostman et al. ${ }^{15}$ study, patient's average age was 33.4 years and the youngest patient age was 19 years and oldest patient age was 62 years.

\section{Sex Incidence}

In this study the patient with comminuted midshaft clavicle fracture, the majority were males, 45 patients $(90 \%)$ and females were 5 patients (10\%).

In Bostman et al. ${ }^{15}$ series also, commonly males are affected 76 patients (73.79\%) compared to females 27 patients $(26.21 \%)$.

\section{Type of Fracture}

In this study, all patients with comminuted midshaft clavicle fractures were of closed type. This is comparable to Bostman et al. ${ }^{15}$ study, which also showed all their patients were closed fractures.

In Kao et al. ${ }^{16}$ study also, all the patients are closed type.

\section{Fracture Classification}

In this present study, there were 38 patients $(100 \%)$ of comminuted midshaft clavicle fracture where Robbinson 2B1 (Simple or single butterfly fragment) 24 patients (63\%) were Robbinson 2B2 (Comminuted or segmental) 14 patients (37\%).

In Bostman et al. ${ }^{15}$ study also Robinson type-2B1 was common in 81 patients (78.64\%). Robinson type-2 B2 occurred only in 22 patients (21.36\%).

\section{Time Interval for Surgery}

In comminuted midshaft clavicle fracture, 38 patients (100\%) where $34(89 \%)$ patients were operated in the first week and 4 patients $(11 \%)$ were operated in the second week.

In Bostman et al..$^{15}$ study all the patients were operated within 3 days of injury.

\section{Duration of Union}

In present study patients with comminuted midshaft clavicle fracture 25 patients $(100 \%)$ treated surgically, 23 patients $(92 \%)$ united at the end of 12 weeks patients (8\%) delayed union occurred.

Lazarus MD. ${ }^{17}$ stated radiological union occurred approximately between 6 to 12 weeks.
One patient (2\%) plated with reconstruction plate for Robinson's type-2 B2 (Displaced and comminuted) was broken at 8 weeks postoperatively. Patient's radiograph during the first followup at 6 weeks showed reconstruction plate bending. In spite of advise, the patient went for his regular occupation and involved in lifting heavy weight before radiological union of the fracture. At the end of 8 weeks postoperatively, the reconstruction plate broke.

In Bostman et al.10 study 2 patients treated with semitubular plate had implant breakage at 2 nd and 7 th postoperative weeks respectively. Both cases were treated by replating using dynamic compression plate with bone grafting.

Delayed union occurred in 2 patients (5\%). In one patient $(4 \%)$ there was a large butterfly fragment in the inferior aspect of clavicle, which went on to unite with the main fragments at the end of 14 weeks.

In another 1 patient $(2 \%)$ delayed union occurred due to plate breakage at 8 weeks postoperatively. Replating with bone grafting was done and it went on to unite at the end of 20 weeks postoperatively.

In Bostman et al. ${ }^{10}$ study delayed union occurred in 3 patients $(2.91 \%)$.

There was cosmetically unacceptable hypertrophic skin scar in 2 patients (5\%). Plate prominence through the skin was reported in 2 patients (5\%).

The total complication in this study were $20 \%$ excluding skin related minor complications.

The total complication rate of Bostman et al. ${ }^{10}$ study was $23 \%$. In this study one patient $(2 \%)$ had superficial infection in the immediate postoperative period, which was controlled with antibiotics for another 5 days.

This in comparison with Kao et al.11 study, there was no complication in 11 patients (91.67\%). In one patient $(8.33 \%)$ had a fall at 2 months after operation. This patient received a revision surgery with distal clavicle resection and coracoclavicular reconstruction.

\section{CONCLUSION}

- Clavicle fractures are usually treated conservatively, but there are specific indications for which operative treatment is needed like comminuted, displaced middle third clavicle fractures and displaced lateral third clavicle fracture.

- Among the internal fixation methods, intramedullary fixation do not control rotation, so they require longer period of immobilization till union.

- In this study, primary open reduction and internal fixation of comminuted midshaft clavicle fractures with locking compression plate provides a more rigid fixation and does not require immobilization for longer periods.

- All the fractures united and there was no nonunion.

- No implant removal was done till the end of this study.

- Clavicle fracture plate and screws fixation and early mobilization gave excellent results in 29 patients.

- In this study, early primary plate fixation of comminuted midshaft clavicular fractures results in improved patientoriented outcomes, improved surgeon-oriented outcomes, earlier return to function and decreased rates of nonunion and malunion. 


\section{REFERENCES}

1. Craig EV, Basamania CJ, Rockwood CA. Fractures of the clavicle. Chapter-11, In : Rockwood CA, Matsen FA, Wirth MA, Lippitt SB, editors, The shoulder. 3rd edition Philadelphia: Saunders, 2004;455-519.

2. Jupiter JB, Leffert RD. Non-union of the clavicle. Associated complications and surgical management. J Bone Joint Surgery (Am) 1987;69:753-760.

3. Hill JM, McGuire MH, Crosby LA. Closed treatment of displaced middle third fractures of the clavicle gives poor results. J Bone Joint Surgery (Br) 1997;79:537-540.

4. Poigenfurst J, Rappold G, Fischer W. Plating of fresh clavicular fractures. Injury 1992;23(4):237-241.

5. Geel CW. Scapula and clavicle. Chapter-4 In Colton CL, Dell'oca AF, Holz U, Kellam JF, Ochsner PE, editors. AO Principles of fracture management, New York:Thieme, 2000;262-264.

6. Bostman O, Manninen M, Pihlajamaki H. Complications of plate fixation in fresh displaced mid clavicular fractures. J Trauma 1997;43:778-783.

7. Lazarus MD. Fractures of the Clavicle. Chapter-26, In: Bucholz RW and Heckman JD, editors, Rockwood and Green's fractures in adults, 5th edition, Philadelphia: Lippincott Williams and Wilkins 2001;1041-1078.

8. Ruedi T and Duwelins PJ. Fractures and dislocations of the shoulder girdle and humerus. Chapter-15, In: Chapman MW, editor, Chapaman's orthopaedic Surgery, Philadelphia, Lippincott Williams and Wilkins, 3rd edition 2001;444-450.

9. Creashaw AH. Fractures of shoulder, arm and forearm. Chapter-54, In:Canale ST, editor. Campbell's operative orthopaeidcs, 10th edition, St. Louis, Mosby, 2003;29853071.

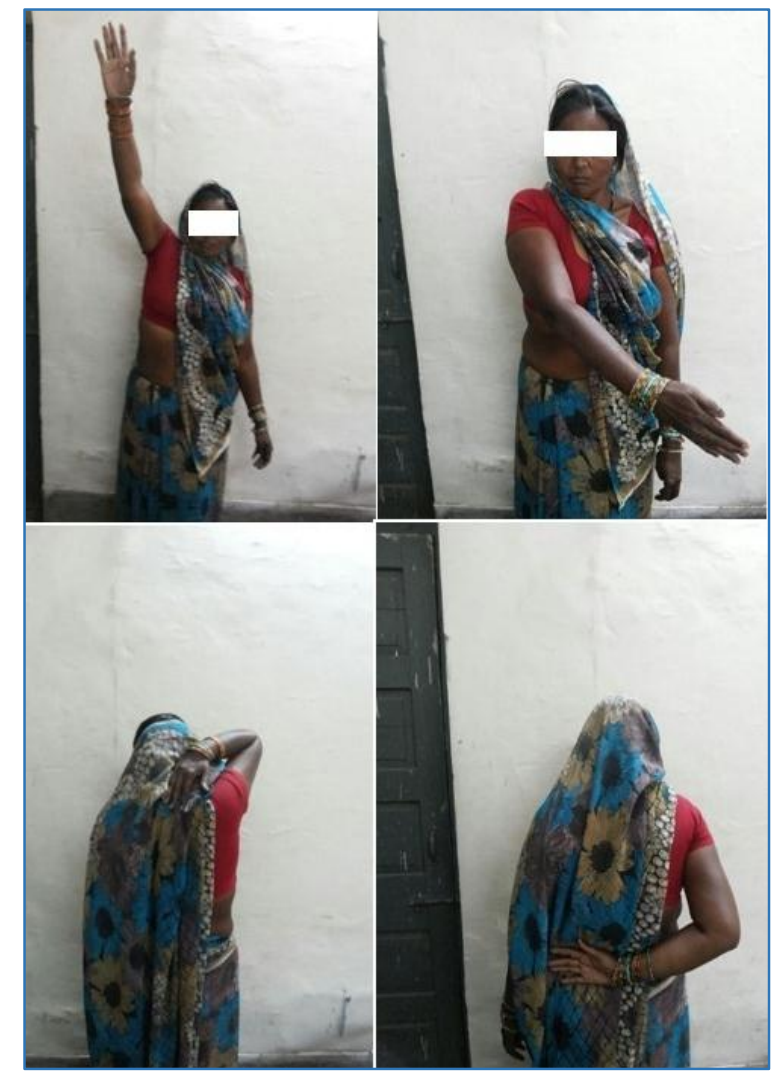

Functional Outcome
10. Constant CR, Murley AHG. A clinical method of functional assessment of the shoulder. Clinical Orthopaedics and Related Research 1987;214:160-164.

11. Labler L, Platz A, Weishaupt D, Trentz O. Clinical and functional results after floating shoulder injuries J Trauma 2004;57:595-602

12. Nordgvist A, Petersson CJ, Redlund-Johnell I. Mid clavicular fractures in adults: end result study after conservative treatment. J Orthop Trauma 1998;12:572576.

13. Robinson CM, Court Brown CM, McQueen MM, Walkefield AE. Estimating the risk of non-union following non-operative treatment of a clavicular fracture. J Bone Joint Surgery (Am) 2004;86:1359-1365.

14. Edwards DJ, Kavanagh TG, Flannery MC. Fractures of the distal clavicle a case for fixation. Injury 1992;23:4446.

15. Bostman O, Manninen M, Pihlajamaki H. Complications of plate fixation in fresh displaced mid clavicular fractures. J Trauma 1997;43:778-783.

16. Kao FC, Chao EK, Chen CH, Yu SW, Chen CY, Yen CY. Treatment of distal clavicle fracture using Kirschner wire and tension band wires. J Trauma 2001;51:522-525.

17. Lazarus MD. Fractures of the Clavicle. Chapter-26, In: Bucholz RW and Heckman JD, editors, Rockwood and Green's fractures in adults, 5th edition, Philadelphia: Lippincott Williams and Wilkins 2001;1041-1078.

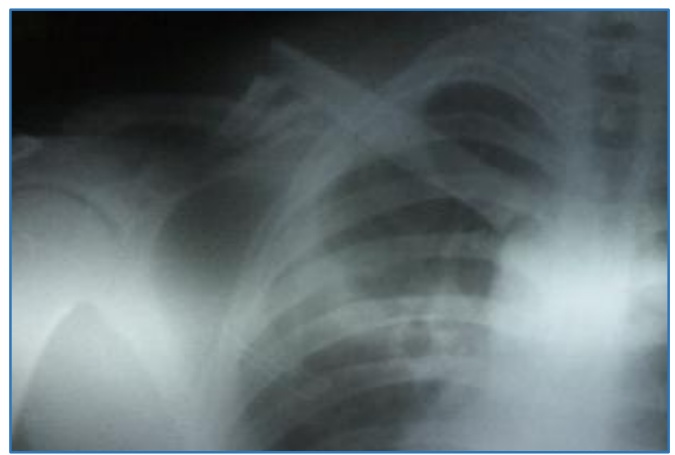

Pre-Operative X-ray

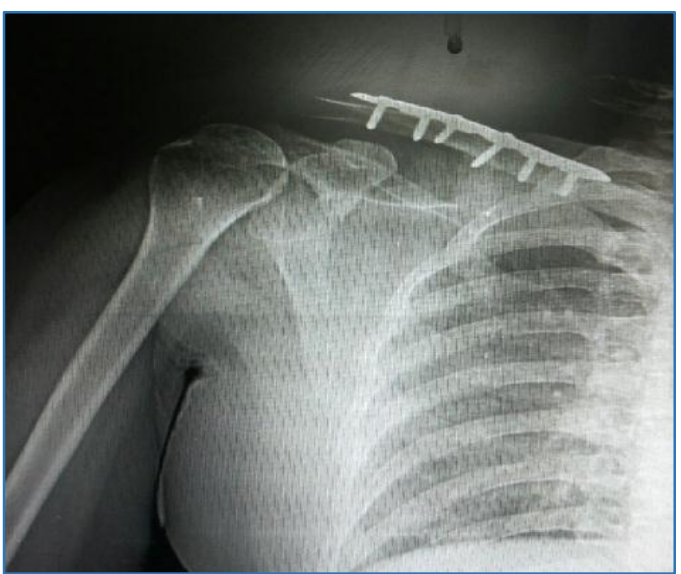

Post-Operative X-ray (Union on 10th week) 